\title{
BIOCHEMICAL CHANGES IN MILK IN EXPERIMENTAL MYCOPLASMAL MASTITIS IN GOATS
}

\author{
JYOTI MISRI ${ }^{1}$, P. P. GUPTA ${ }^{1}$, S. P. AHUJA ${ }^{2}$ \\ Department of Veterinary Pathology 1 and Biochemistry 2 \\ College of Veterinary Science, Punjab Agricultural University \\ Ludhiana (India)
}

Received July 23, 1987

\section{A b s $t r a c t$}

$M$ i s r i J., P. P. G $u$ p $t$, S. P. A $h u j a$ : Biochemical Changes in Milk in Experimental Mycoplasmal Mastitis in Goats. Acta vet. Brno, 57, 1988: 19-30.

To study the biochemical changes in milk during experimental mycoplasmal mastitis, 11 lactating goats were taken and $2 \mathrm{ml}$ of Mycoplasma mycoides subsp. capri culture containing $10^{7}$ colony forming units per $\mathrm{ml}$ were inoculated through the teat canal into their right udder halves. The left udder halves of all the goats inoculated with sterile mycoplasma broth served as control. Three animals were killed each on third, eighteenth and twenty-fifth day and two on seventh day post-inoculation. A11 the goats developed clinical mastitis within $24 \mathrm{~h}$ after inoculation of Mycoplasma culture, which persisted till the end of the experiment. The total protein, total cholesterol, total phospholipids and free fatty acid content of halves of goats given intra-mammary inoculation of $\underline{M}$. mycoides subsp. capri were progressively increased with the increase in days after inoculation. On the other hand the total lipids and glyceride content was decreased substantially with the increase in the postinuculation period. The milk/mammary secretions from the control and inoculated udder halves after scanning of proteins fractionated by polyacrylamide gel electrophoresis showed that the number and proportions of various protein bands were modified by Mycoplasma infection.

Milk, biochemical changes, mycoplasmal mastitis, goats, udder.

It has been reported ( $P$ r a s a d et al. 1985) that Mycoplasma infection in goat produces sudden drop in milk yield with marked reduction in the size of the secretory mammary tissue and without systematic reaction. No work appears to have been done on the composition of milk after Mycoplasma infection of goat udder. The present work was, therefore, undertaken to study the qualitative and quantitative changes in lipids and protein in milk during experimentally produced mycoplasmal mastitis in goats. 
Mat e r i a 1 s a nd Me thod s

Eleven lactating goats aged from 2,5 to 4 years were kept under observation for 7 days before starting the experiment. A11 were found healthy and free of subclinical mastitis. The total leucocyte count (TLC) of milk ranged from 0.28 to $0.52 \times 106 \mathrm{ml}^{-1}$. No bacteria, Mycoplasma or fungi could be isolated from milk samples. Two $\mathrm{ml}$ of a $48 \mathrm{~h}$ culture of $M$. mycoides subsp. capri, at seventh passage level, conaining 107 colony forming units $\mathrm{ml}^{-1}$ was inoulated through the teat canal into the right half of the udder of all the 11 goats. The left halves of udders of these goats were inoculated with $2 \mathrm{~m} 1$ of sterile mycoplasma broth and served as control. The temperature of all goats was taken daily, and they were examined for development of abnormal changes in the udder, as well as for any evidence of systemic disturbances and mastitis as assessed by the California mastitis test (CMT) and the modified whiteside test. Pre and postinoculation samples of the milk/mammary secretions were obtained from all the goats on third, seventh, eighteenth and twenty-fifth day after inoculation and were cultured on mycoplasma medium (B a $n$ e $r^{*}$ $j \mathrm{e} e$ et a1. 1979), blood agar and Saboraud's Dextrose agar. Total leucocyte counts (TLC) of milk/mammary secretions and haematological values of all the goats were also recorded. Total lipids (F o $1 \mathrm{ch}$ et al. 1957), total phospholipids (A m e s 1966), total cholesterol ( $\mathrm{z} 1$ a t $k$ i s and $\mathrm{T} i \mathrm{n}$ s 1 e y 1976), total glycerides (by difference), total proteins ( $\mathrm{s}, \mathrm{w} \mathbf{r} \mathrm{y}$ et al. 1951), and proteins in milk/mammary secretions were characterized by polyacrylamide gel electrophoresis (PAGE, D a v i s 1964), and they were determined before and after inoculation of Mycoplasma.

The experiment was continued for 25 days. Three animals were killed each on third, eighteenth and twenty-fifth day and 2 on seventh day after inoculation. All the organs including udders and mammary lymph nodes, were examined grossly and microscopically. For microscopic examination, 5 to $6 \mu$ thick paraffin secretions, were stained with haematoxylin and eosin. The udder tissues and mammary lymph nodes from both halves of each goat were also cultured for Mycoplasma isolation as described by $B$ a $n$ e $r j$ e et a1. (1979).

Body temperature and appetite remained unaffected. The right halves of the udder of all the 11 goats inoculated with M. mycoides subsp. capri, became, hot, tender and painful 2 days after being inoculated. Five days later the halves began to become smaller and by 18 days after inoculation they were firm and markedly reduced in size (Fig. 1). Thereafter, these inoculated halves further became smaller and became more firm until the end of the experiment. Milk/mammary secretions from these halves decreased from the third day after infection and from eighteeenth day these became agalactic as only 2-3 drops of milk/secretions could be drawn till the end of experiment. The milk/mammary secretions from the infected 

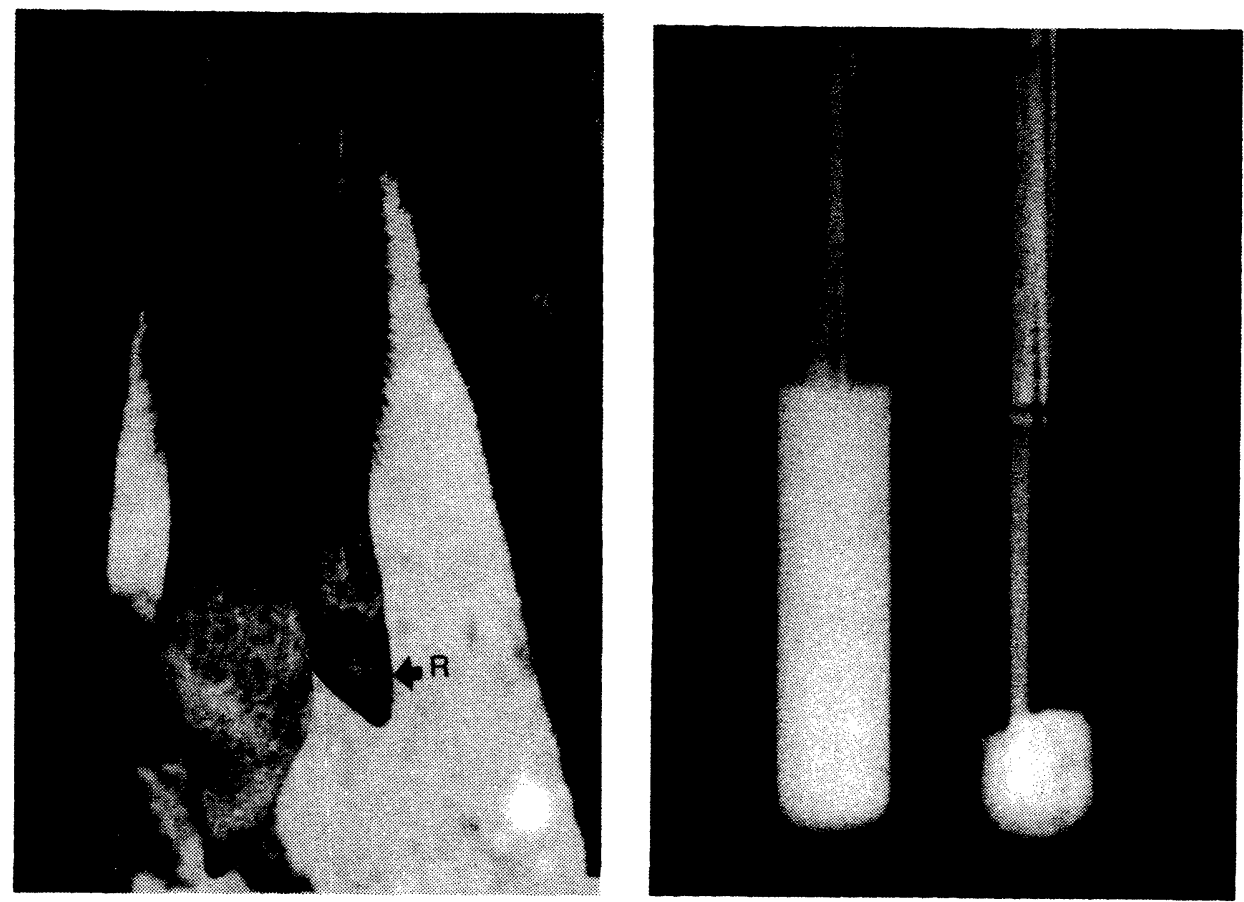

Fig. 1. Reduction in the size of right half of the udder of goat after 18 days of inoculation of M. mycoides subsp. capri culture
Fig. 2. Right - Milk from right udder half of a goat inoculated with $\underline{M}$. mycoides subsp. capri showing precipitation of proteins and clear supernatant fluid 10 days after inoculation. Left - Normal milk from left udder half of the same animal.

gland were yellowish, turbid, thick and upon being kept, the proteins precipitated leaving a clear whey-like supernatant fluid (Fig. 2). The milk from the left half of all the udders remained normal. Mastitis in the right halves was evident within $24 \mathrm{~h}$ after inoculation but was severe from third to the eighteenth day, after which it subsided, as is evident from the decrease in TLC.

The TLC of milk/mammary secretions from inoculated halves increased from the basal values of $0.389 \times 10^{6} \mathrm{ml}^{-1}$ to $3.84 \times 10^{6} \mathrm{ml}^{-1}$ on the third day and $5.90 \times 106 \mathrm{ml}^{-1}$ on the seventh day after inoculation. However, there was a slight decrease in the TLC of milk on the eighteenth 


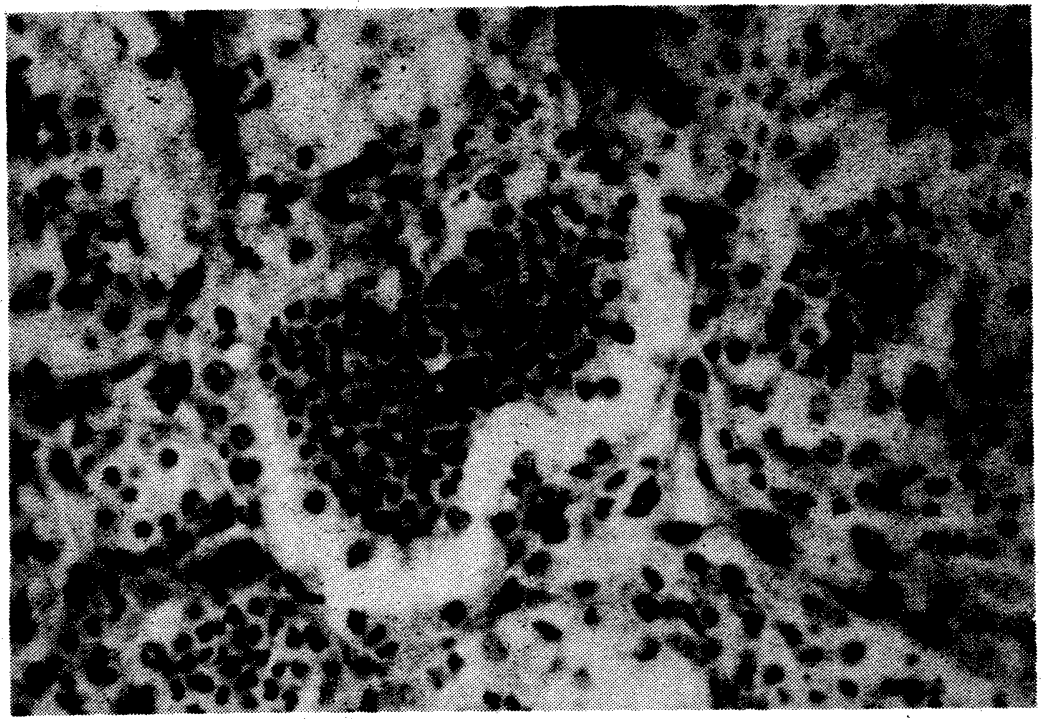

Fig. 3. Section of right udder half of goat showing acute diffuse purulent mastitis after 3 days of inoculation of Mycoplasma . HE $\times 300$.

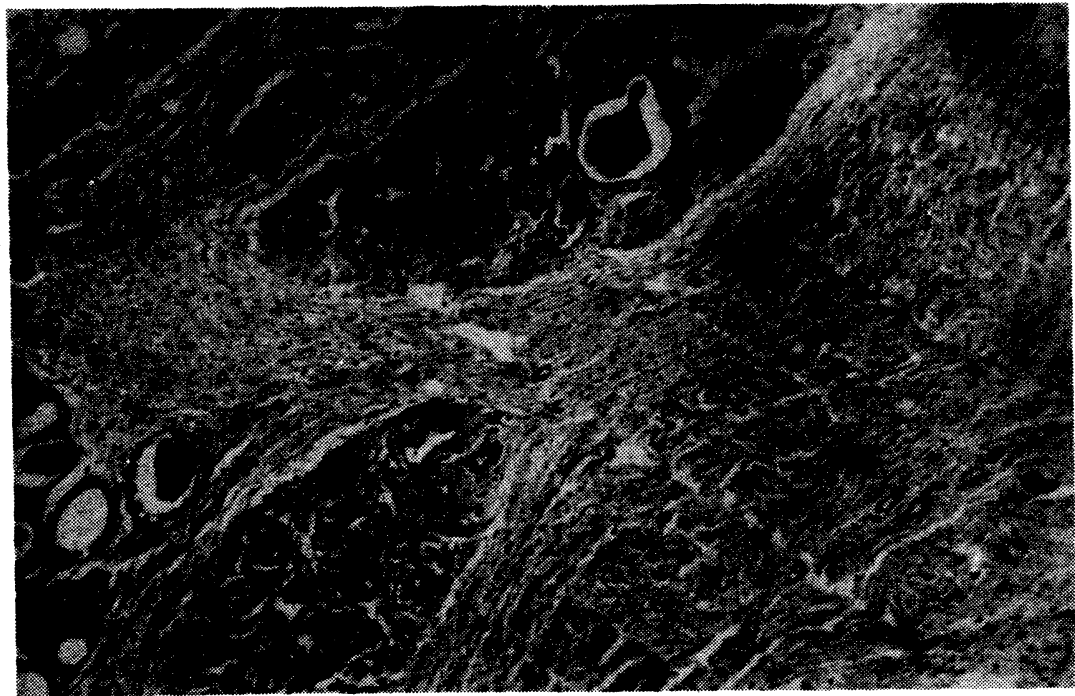

Fig. 4. Section of right udder half of a goat killed 18 days after inoculation of Mycoplasma, showing marked fibrosis in the interlobular septa and atrophy of the glandular lobules. HE $\times 70$. 


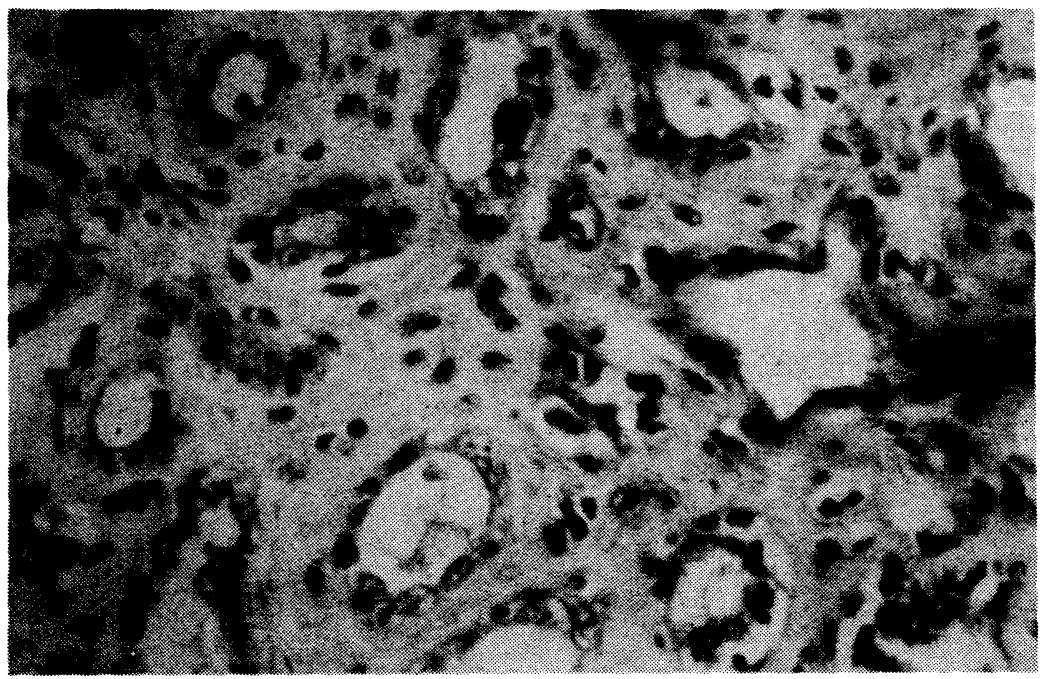

Fig. 5. Higher magnification of Fig. 4 showing marked fibrosis and infiltration of chronic inflammatory cells in the periacinar connective tissue leading to the decrease in the size of acini and at places the acini have been replaced by fibrous tissue. HE $\times 300$.

day $\left(3.10 \times 10^{6} \mathrm{ml}^{-1}\right)$ and on the twentyfifth day $(2.50$ $\times 10^{6} \mathrm{ml}^{-1}$ ) after inoculation. The TLC in milk from control halves remained unaffected and low.

The TLC of blood increased from the seventh day after inoculation $\left(10.42 \times 10^{3} \mathrm{cmm}^{-1}\right.$ of blood as compared to the basal value of $8.64 \times 10^{3} \mathrm{cmm}^{-1}$ ) and reached a maximum of $12.3 \times 10^{3} \mathrm{cmm}^{-1}$ eleven days later. Other haematological parameters viz. haemoglobin, differential leucocyte count did not show any significant change.

M. mycoides subsp. capri was re-isolated from milk/mammary secretions, udder tissues and mammary lymph nodes of all the affected halves at the third, seventh and eighteenth day after inoculation, whereas it was not isolated from the milk, udder tissues and mammary lymph nodes of left halves infused with sterile mycoplasma broth. No bacterial or fungal agent was isolated from milk/mammary secretions of any goat during the experiment.

Microscopically, right udder halves of all the animals killed on days 3 and 7 after inoculation showed acute 


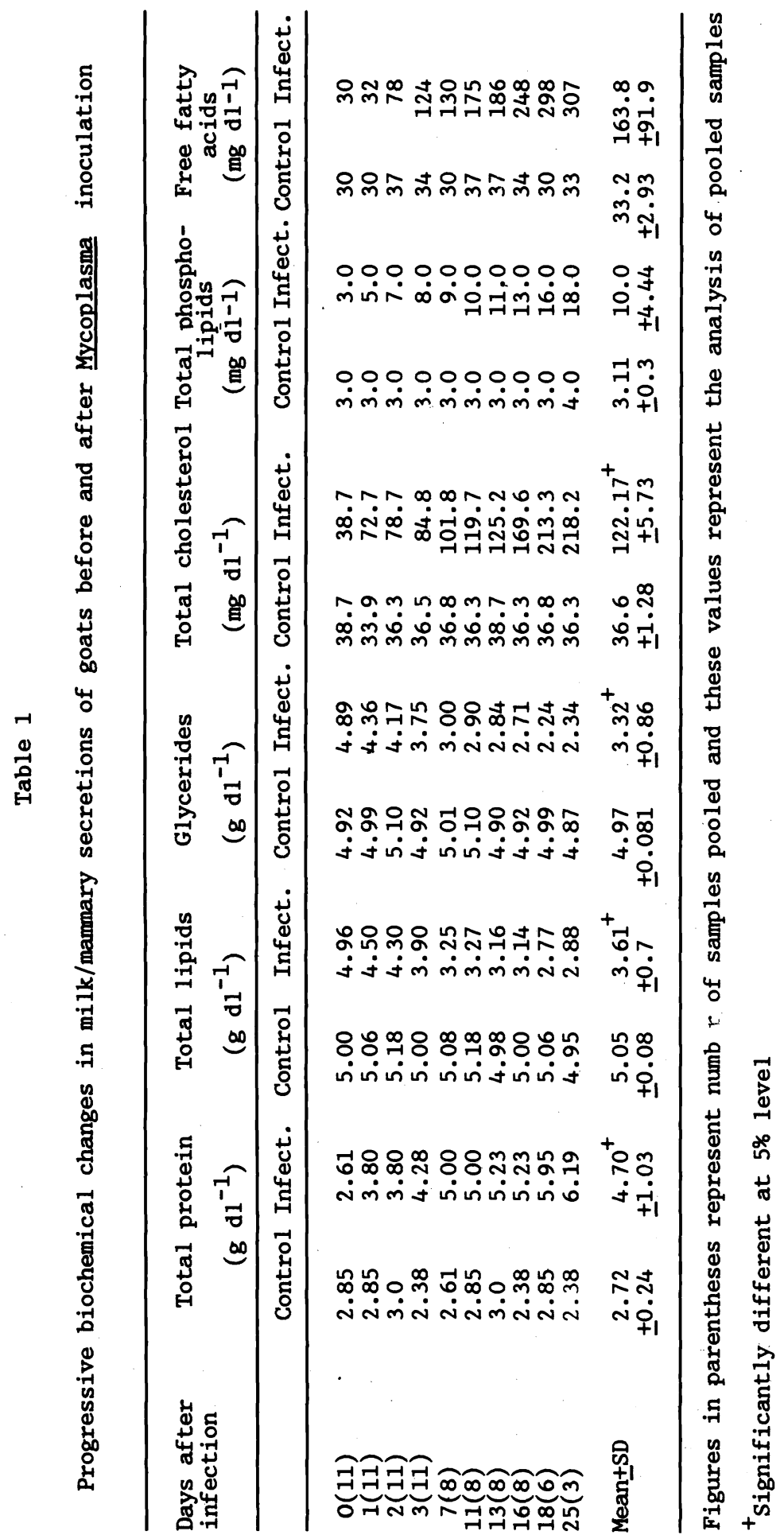


diffuse purulent mastitis, characterized by marked infiltration of neutrophils in the lumina of acini and vacuolar degeneration in epithelial cells lining the acini (Fig. 3). The left udder halves of these animals did not show any abnormal changes and contained normal milk. Eighteen days after inoculation, the right udder halves showed chronic interstitial mastitis with marked fibrosis in the interlobular septa and periacinar interstitial tissue leading to the thickening of interlobular septa and decrease in the size of lobules (Fig. 4). The lobules were subdivided into pseudolobules by penetrating fibrous connective tissues. There was a marked decrease in size of acini with periacinar fibrosis and at places the acini were replaced by fibrous tissue. There was a marked infiltration of chronic inflammatory cells in the interstitial tissue (Fig.

5). Twenty-five days after inoculation the changes in the right udder halves were more severe and chronic than those observed at day 18 after inoculation. The left udder halves of these animals did not show any pathological change.

The total protein, total cholesterol, total phospholipids and free fatty acid content of mastitic milk/mammary secretions, from the udder halves of goats given intrammary infusion of Mycoplasma mycoides subsp. capri were progressively increased significantly with time after inoculation. The total lipids and glyceride content was dereased substantially with the increased length of the post-inoculation period (Table 1).

Total lipids in mastitic milk/mammary secretions were reduced significantly and ranged from 2.77 to $4.96 \quad \mathrm{~g} \mathrm{dl}^{-1}$ as compared to $5.05 \pm 0.08 \mathrm{~g} \mathrm{dl}^{-1}$ in normal milk. Total protein content in māstitic milk/mammary secretions was increased and ranged from 2.61 to $6.19 \mathrm{~g} \mathrm{dl}^{-1}$ as compared to that of normal value of $2.72 \pm 0.24 \mathrm{~g} \mathrm{dl}^{-1}$.

The glyceride content was decreased in the mastitic milk/mammary secretions and ranged from 2.24 to 4.89 $\mathrm{g} \mathrm{dl}^{-1}$ as compared to that of normal values of $4.97 \pm$ $0.08 \mathrm{~g} \cdot \mathrm{dl}^{-1}$ total cholesterol content increased in mastitic milk/mammary secretion and varied from 38.7 to $218 \mathrm{mg}$ $\mathrm{dl}^{-1}$ as compared to the normal value of $36.6 \pm 1.28 \mathrm{mg}$

Total phospholipid content obtained from mastitic milk/mammary secretions was increased and varied from 3.0 to $18.0 \mathrm{mg} \mathrm{dl}^{-1}$ as compared to that of normal value 
of $3.11 \pm 0.3 \mathrm{mg} \mathrm{dl}{ }^{-1}$. The free fatty acids content in mastitic milk/mammary secretions was increased and varied between 30 to $307 \mathrm{mg} \mathrm{dl}^{-1}$ as compared to the normal value of $33.2 \pm 2.93 \mathrm{mg} \mathrm{dl}{ }^{-1}$. All the biochemical changes produced in mammary secretions after inoculation, were significant at 5 per cent level (Table 1).

The number of proteins fractionated by PAGE were 5 in control milk. Their molecular weights ranged from 10 $\mathrm{Kd}$ to about $240 \mathrm{Kd}$ as determined from the relative mobilities. The mastitic milk/mammary secretions collected on days $1,2,3,7,11,13,16,18$ and 25 after Mycoplasma inoculation showed 6 to 12 protein bands some of which were of different molecular weights than those in the control milk (Fig. 6). The milk/secretions respectively from control and inoculated udder half 25 days post inoculation, fractionated by PAGE and then scanned by densitometry (Fig. 6) showed that the proportions of high molecular weight of various proteins was decreased by Mycoplasma infection (Fig. 6) and the number and proportions of relatively low molecular weight proteins was increased.

\section{D is c u s s i o n}

The re-isolation of $M$. mycoides subsp. capri from the mammary secretions even on the 18th day post-inoculation confirmed that the mastitis was of mycoplasmal origin. The increased TLC and cessation of mammary secretions of goats after inoculation with $\underline{M}$. mycoides subsp. capri are similar to those described in contagious agalactia caused by $M$. agalactiae $(H$ e $i$ d $r$ i $h$ and $R$ e $n$ k 1967; $B$ a r - Mos h e and $R$ a p a p o r t 1978; C o t t e $\mathrm{w} 1979$; $\mathrm{B}$ a $\mathrm{r} t \mathrm{t} \mathrm{n}$ and $\mathrm{C}$ o $\mathrm{t} t \mathrm{e} w$ 1980), $\mathrm{M}$. putrefaciens mastitis in goats (A d.l e r et al. 1980) and $\underline{M}$. bovis mastitis in cows ( $R \mathrm{u} \mathrm{h} \mathrm{k}$ e et al. 1976). Above observations are also similar to the findings in goats inoculated with $M$. agalactiae subsp. bovis $(O j a$ and I $k$ e d e 1976), $\overline{\mathrm{M}}$ bovigenitalium $(\overline{\mathrm{P} a} 1$ et al. 1983), M. arginini ( $\mathrm{P} r$ a $\mathrm{s}$ a et al. 1985) and in cows inoculated. with $M$. bovis mastitis ( $\underline{e} n \mathrm{n}$ e $t$ and $J$ a s p e $r$ 1978).

The increase in total protein, cholesterol, phospoholipids and free fatty acid content of milk/mammary secretions 


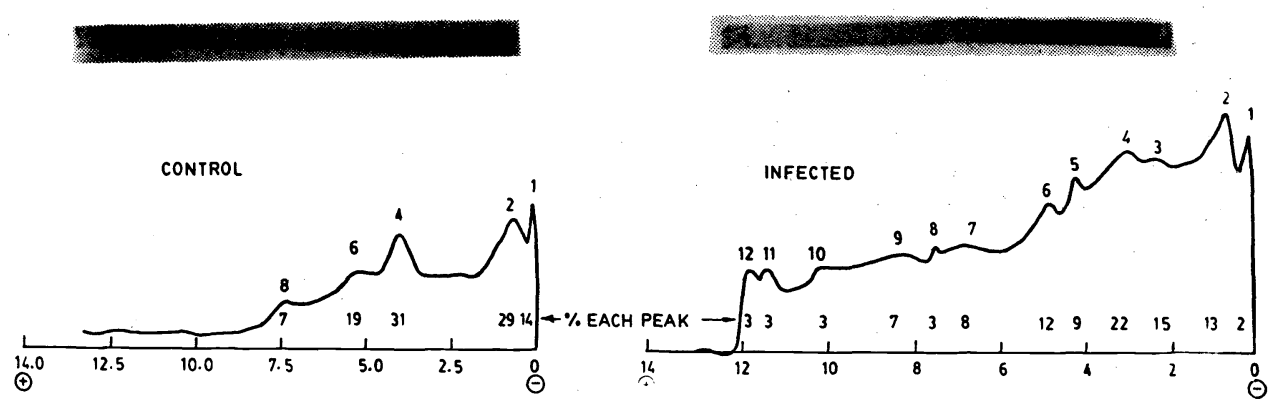

Fig. 6. PAGE scan pattern of the control goat milk and mastitic mammary secretion (25th day) showing proportions and nature of each protein

from the goats given intrammary inoculation of $M$. mycoides subsp. capri and decreased total lipid and glyceride content respectively indicated increased cellular contents, and lipase activity due to the presence of Mycoplasma. The presence of non-specific lipase, capable of hydrolysis of glycerides, fatty acid esters has been reported in some species of Mycoplasma (S m i t h 1979).

The increase in cholesterol content indicated that Mycoplasma hydrolyses cholesterol esters, but does not catabolize cholesterol, and retains the cholesterol for biosynthesis of its own membranes. S $m$ i t h (1979) also demonstrated the presence of cholesterol esters in $M$. arthritidis, M. gallinarum and A. laidlawii. Mycoplasmas are known to require preformed cholesterol for their growth ( $S \mathrm{~m} i \mathrm{t} h$ 1979), therefore, the cholesterol present in the mammary secretions may be used by these organisms for formation of their membranes and for their multiplication. The increase in total phospholipids and the protein content of mastitic milk/mammary secretions from the right inoculated udder halves of the goats supported these conclusions, viz. production of higher content of membranous material of the Mycoplasma. The higher levels of these constituents may also be due to the presence of membranes of the 
lymphoid cells whose numbers were increased. It may also be due to the mucilaginous secretions induced by Mycoplasma infection.

Comparison of the PAGE pattern (Fig. 6) of the control milk and the mastitic mammary secretions from the inoculated udder halves indicated the presence of additional protein bands, both of low and very high molecular weights which are not present in normal milk. These additional proteins most probably originate from the Mycoplasma organisms and also from the mycoplasmal degradation of milk protein as these are absent in normal milk. The presence of some of the proteins of electrophoretic mobilities similar to additional proteins detected during their studies have been reported by $\mathrm{R}$ a z i n (1979) in membranes of A. laidlawii, confirming in part the mycoplasmal origin of these proteins in milk/mammary secretiors from infected udder.

The data on the effect of Mycoplasma infection on the composition of mastitic milk/mammary secretions of goats is not available. However, biochemical changes in the mammary gland secretion of different species with bacterial mastitis are available (A $g$ a $r$ w a 1 and $N$ a $r$ a y a $\mathrm{n}$ a $\mathrm{n}$ 1976; $\mathrm{M}$ a $\mathrm{n}$ d a 1 et al. 1977; $\mathrm{M}$ a $\mathrm{n}$ d $\mathrm{l}$ and $A \quad h \quad u \quad a$ 1985). These workers also reported increase in free fatty acids $(M$ a $n$ a 1 et al: 1977; $R$ a $n-$ d o $1 \mathrm{p} \mathrm{h}$ and $\mathrm{E} r \mathrm{w} \mathrm{i}$ 1977; 1974) cholesterol (M a n $d$ a 1 and $R$ a $h^{\circ}$ e $j$ a 1985), phospholipids (A g a r $\mathrm{w}$ a 1 and $\mathrm{N}$ a $\mathrm{r}$ a $\mathrm{y} \mathrm{n}$ a $\mathrm{n}$ 1976) and decrease in total lipids/glycerides ( $\mathrm{M}$ a $\mathrm{n} \mathrm{d}$ a 1 et al. 1985) after bacterial infections. Such reports and the results of the present study indicate that mastitis of microbial origin in general produces hydrolysis of milk lipids. The vacuolar degeneration in epithelial cells lining the acini, marked fibrosis in the interlobular septa and periacinar interstitial tissues and replacement of acini with fibrous connective tissue indicated decrease in the mass of the secretory tissue leading to agalactia.

Biochemické změny $v$ mléce při experimentální mastitidě vyvolané Mycoplasma mycoides

Pro studium biochemických změn $v$ mléce $v$ průběhu experimentální mastitidy vyvolané mykoplasmaty bylo použito 11 laktujících koz, jimž byly přes strukové kanálky do pravé 
poloviny vemene inokulovány $2 \mathrm{ml}$ kultury Mycoplasma mycoides subsp. capri s obsahem $10^{7} \mathrm{CFU}$. $\mathrm{ml}^{-1}$.

Levé poloviny vemen těchto zvírat inokulované sterilním bujonem pro kultivaci mykoplasmat, sloužily jako kontroly. Tř̉i zvírata byla utracena třetí, pak osmnáctý a pětadvacátý den po inokulaci, dvě zvírata sedmý den po inokulaci. Do $24 \mathrm{~h}$ po inokulaci se $u$ všech zvírat vyvinula klinická mastitida, která přetrvávala do konce pokusu. Koncentrace celkových bílkovin, celkových fosfolipidů a volných mastných kyselin $v$ mléce (resp. sekretu mléčné žlázy) změněném zánětem mléčné žlázy $\mathrm{z}$ polovin vemen inokulovaných $\underline{M}$. mycoides subsp. capri se progresivně zvyšovala $\frac{\text { s. }}{\mathrm{s}}$ přibývajícími dny po infekci. Naopak, koncentrace celkových lipidů a glyceridu se podstatně snižovala. Mléko (resp. sekret $z$ mléčné žlázy) z kontrolních a pokusných polovin vemen obsahovalo také změněné frakce bílkovin, vyvolané infekcí Mycoplasma mycoides.

Биохимические изменения молока при эксперименталъном мастите, вызванном Mycoplasma mycoides

Для исследования биохимических изменений в молоке в ходе эксперименталъного мастита, вызванного микоплазмами, исполъзовали 11 лактирующих коз, которым инокулировали через каналъцы соска в правую половину вымени 2 мл кулътуры Mycoplasma

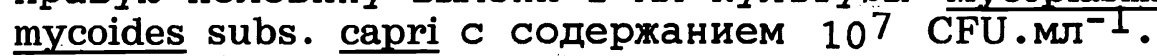
Левая половина вымени данных животных, инокулированная кулътивирования трое жиботных восемнадцатые и инокуляции, двое после инокуляции. стерильным микоплазмы, стала контролъной. были умерщвлены на третъи, двадцатъ пятые сутки после животных - на седъмые сутки Через сутки после инокуляции Y всех животных развился клинический мастит, длящийся до конца эксперимента. Концентрация общих белков, общих ФосФолипидов, свободных жирных кислот в молоке или секрете молочной железы, измененном ее воспалением, из половины вымен, инокулированных M. mycoides subsp. capri прогрессивно увеличиваласъ с прибываюими после инфекции сутками. Наоборот, концентрация общих липидов и глицерида существенно понижаласъ. Молоко (или секрет молочной железы) контролъных и 
эксперименталъных половин вымени содержало также измененные Фракции белков, вызванные инфекцией Mycoplasma mycoides.

\author{
Ref e r e n e s
}

ADLER, H. E. - DA MASSA, A. J. - BROOKES, D. L.: Caprine mycoplasmosis: Mycoplasma putrefaciens, new cause of mastitis in goats. Am. J. Vet. Res., 41 , 1980: 1677-1679

AGARWAL, V. K. - NARAYANAN, K. M.: Influence of mastitis on the physicochemical status of milk lipids. I. Glycerides free fatty acids and phospholipids. The Indian J. Dairy Sci., 29, 1976: 83-87

AMES, B. N.: Assay of inorganic phosphate and phosphatases. In: Methods in Enzymology, Academic Press, New York, Vol. 8, 1966, pp. 115-118

BANERJEE, M. - SINGH, N. - GUPTA, P. P.: Isolation of mycoplasmas and acholeplasmas from pneumonic lesions in sheep and goats in India. Zbl. Vet. Med. B., 26, 1979: 689-95

BAR-MOSHE, B. - RAPAPPORT, E.: Contagious agalactia like disease in goats caused by Mycoplasma mycoides subsp. mycoides (ovine/caprine) serotype 8. Rafuah Veterinarith, 35, 1978: 75-77

BARTON, M. D. - COTTEW, G. S.: Mycoplasmosis in goats. Aust. Vet. J., 56, 1980: 614-615

BENNET, R. H . - JASPER, D. E.: Immunologic and pathogenic response of cow to naturally occurring Mycoplasma bovis mastitis. Ve. Microbio1., 2, 1978: 325-334

DAVIS, B. J.: Disc Electrophoresis. II. Method and application to human serum proteins. Ann. N. Y. Acad. Sci., 121, 1964: 404

FOLCH, J. - LESS, M. - STANLEY, G. H. S.: A simple method for the isolation and purification of total lipids from animal tissues. J. Biol. Chem., 226, 1957: 497-507

HEIDRICH, H. J. - RENK, W.: Diseases of mammary glands of domestic animals. W. B. Saunders Company, Philadelphia, London, 1967

LOWRY, 0. H. - ROSENBROUGH, N. J. - FARR, A. L. - RANDALL, R. J.: Protein measurement with Folin-phenol reagent. J. Biol. Chem., 193, 1951: 265-275

LOWRY, R. R. - TINSLEY, I. J.: Rapid colorimetric determination of free fatty acids. J. Am. Oil. Chem., Soc., 53, 1976: 470-472

MANDAL, P. C. - AHUJA, S. P.: Observations on experimental mastitis in an Ewe and a goat induced by Klebsie1la pneumoniae. Archiva Veterinaria, 17, 1985: 85-88

MANDAL, P. C. - RAHEJA, R. K.: Influence of mastitis on the milk 1ipids in Indian buffaloes (Bubalus bubalis). Archiva Veterinaria, 17, 1985: 99-102

MANDAL, P. C. - SHARMA, D. R. - AHUJA, S. P.: Observations of a spontaneous case of fatal ovine mastitis due to Klebsiella pneumoniae. Zbl. Vet. Med. B, 24, 1977: 168-174

OJO, M. 0. - IKEDE, B. 0.: Pathogenicity of Mycoplasma agalactiae subsp. bovis in goats mammary gland. Vet. Microbio1., 1, 1976: 19-22

PAL, B. C. - SINGH, P. P. - PATHAK, R. C.: Mycoplasma bovigenitalium pathogenicity for caprine udder. Indian J. Comp. Micro. Imm. Infect. Diss., 4, 1983: 262-263

PRASAD, L. N. - GUPTA, P. P. - SINGH, N.: Experimental Mycoplasma arginini mastitis in goats. Aust. Vet. J., 62, 1985: 341-342

RANDOLPH, H. E. - ERWIN, R. E.: Influence of mastitis on properties of milk, fatty acid composition. J. Dairy Sci., 57, 1974: 865-868

RUHNKE, H. L. - THAWLEY, D. - NELSON, F. C.: Bovine mastitis in Ontario due to Mycoplasma agalactiae subsp. bovis. Can. J. Comp. Med., 40, 1976: 142-148

SMITH, P. F.: The composition of membrane lipids and 1ipopolysaccharides. In: The Mycoplasmas. Vol. I, Cel1 Biology. Academic Press, N. Y., 1979: pp. 231-257

ZLATKIS, A. - ZAK, B.: Study of a new cholesterol reagent. Anal. Biochem., 29, 19.69: 143-148 